\title{
What is the Use of the Notion Of the Struggle of RECOGNITION?
}

\author{
¿A qué sirve la noción de un conflicto de reconocimiento?
}

\author{
EMMANUEL RENAULT \\ Ecole Normale Superieure de Lyon
}

\begin{abstract}
RESUMEN
Este artículo contribuye al debate sobre el reconocimiento a través de un análisis de la relación entre reconocimiento y conflicto social, y explica por qué las teorías del reconocimiento son de importancia hoy en día para la teoría política. En un primer momento, el artículo presenta las contribuciones de Taylor, Fraser y Honneth al debate sobre el reconocimiento. En segundo lugar, se introduce la distinción entre conflictos de reconocimiento de tipo agonístico y los de tipo consensuado. Finalmente, el artículo ilustra las relaciones entre instituciones y reconocimiento y los diversos tipos de problemas que un análisis de las demandas de reconocimiento debe de enfrentar.
\end{abstract}

Palabras clave: Política del reconocimiento, política agonística, identidad, movimientos sociales, institucionalización.

\begin{abstract}
This article intervenes in the debate going on in philosophy and sociology regarding recognition and, in particular, the idea of a struggle of recognition. It seeks to make the meaning of the link between recognition and struggle explicit, as well as to discuss reasons for why theories of recognition could provide interesting insights into political theory. In a first step, it confronts Taylor's, Fraser's and Honneth's contribution to the debate on recognition. In a second step, it introduces the distinction between agonistic and consensual struggles of recognition. In a third step, it describes the relationships between institutions and recognition and the various problems that an analysis of claims for recognition has to tackle with.
\end{abstract}

Key words: Politics of recognition, agonistic politics, identity, social movements, institutionalization.

For more than 15 years, there has been a debate going on in philosophy and sociology regarding recognition. One of its main themes is the struggle for recognition. This article aims to make the meaning of the link between recognition and struggle explicit, as well as to discuss reasons for why theories of recognition could provide interesting insights into political theory.

What is the use of the notion of the struggle of recognition? A classical answer is that one needs to distinguish between the two types of social movements and political struggles. Instead of being oriented toward just distribution and respect for universal rights, new social and political movements would be oriented toward the recognition of identities. From an historical (old vs new) as well as from a normative (justice vs identity) standpoint, the use of the idea of a struggle for recognition would be to help specify particular collective claims. But, a theory of recognition has also other possible uses. It can make the practical 
and normative dynamics of protest action explicit. An analysis of the various modes by which recognition is denied, and of the various practical and normative reactions to such denial, can also provide interesting typologies of protest actions.

\section{STRUGGLE FOR RECOGNITION AND POLITICS OF IDENTITY}

The notion of a politics of identity seems to be closely linked with the debate between liberalism and communitarianism. Whereas liberalism claims that individual rights of negative freedom have priority over collective rights and rights to positive freedom, communitarianism tries to promote rights to "cultural survival". In this debate, the idea of a "politics of identity" refers to the right to defend cultural identities incorporated in religion or language under restricted conditions. In Charles Taylor's classical contributions to this debate, the notion of a "politics of recognition" is identified with such "politics of identities". ${ }^{1}$ Here, "recognition" means collective agreement that these cultural identities are part of the possibility of a good life and that, therefore, they have to be protected by laws and in institutional settings. In this sense, political endeavours to defend theses cultural identities can be conceived of as a "struggle for recognition", that is, a struggle aimed at attaining recognition of given cultural features by members of a political public sphere that do not share the same culture. The very notion of recognition, moreover, enables us to describe the legitimacy of such claims. As a matter of fact, for people that share given cultural features, the very possibility of self realization is undermined if these features are stigmatized or structurally devalued. Inter-subjective recognition of my identity is a precondition for having a good life. Thus, this theory of recognition is of interest for two reasons: first, it enables one to distinguish the specificity of these political claims and, second, it makes the specific legitimacy of theses claims explicit.

Indeed, such cultural struggles seem to be a more recent phenomena than struggles for human rights or social justice. In a broader sense, the idea of a "politics of recognition" is meant to denote the features shared by the "new social movements". According to Nancy Fraser, one can distinguish between two kinds of struggles for social justice. The first one is exemplified by the classical socialist movement and is oriented toward equality in redistribution. ${ }^{2}$ The second one is exemplified by new social movements and aims for equal recognition not only of cultural identities, but also of collective identities defined by sexual orientation, gender constructions and ethnic and racial prejudices. For Fraser, it is impossible to reduce the issue of recognition to that of distribution, and vice versa. She also argues that in most social struggles, both of these issues are intertwined. For instance, even if feminist or antiracist politics are above all struggles for recognition, they also have a distributive aspect (low female incomes, the restriction of foreigners to menial jobs, etc.). Fraser classifies her position as "perspectivist dualism": she asserts that redistribution and recognition are to be conceived of as two perspectives on justice 
and not as autonomous spheres of justice. Here, we can see that a theory of recognition works toward different aims than it does in Taylor. Its main intention is to show, on the one hand, that the classical political language of socialism is unable to deal with the new political claims of gender and ethnicity, but, on the other hand, it makes no sense to try to replace a politics of redistribution with a politics of identity.

Fraser's position rests on two premises that have been criticized by Axel Honneth. ${ }^{3}$ From an historical standpoint, one can notice that the struggle for redistribution in the labour movement has been closely linked with various kinds of cultural struggles. E. P. Thompson's classical book The Making of the English Working Class gives much evidence in support of this claim. ${ }^{4}$ To provide another illustration, it is striking that in the first labour newspaper in Europe, l'Echo de la Fabrique (Lyon, 1831-1834), a public competition was organized in order to replace the stigmatized name of the silk workers ("canuts"). And it is also interesting to note that in between the two famous revolts of 1831 and 1834, some "canuts" proposed to fight for the social honour of their profession with a new name, whereas others defended this name and, on the contrary, proposed to reverse the stigma. ${ }^{5}$ Following Honneth, one may wonder if the gap between redistribution and recognition is really impossible to bridge. As a matter of fact, many distributive injustices are experienced by individuals as a lack of recognition of the social value of their work.

Furthermore, according to Honneth, in all cases of injustice, a denial of recognition is at stake. Therefore, the very project of a theory of recognition becomes quite different than it is in Taylor and Fraser. Since social and political movements are reactions to feelings of social or political injustice, a theory of recognition can be conceived of as a "normative grammar of social conflicts". Such a theory works toward different goals. It aims to show that social movements have not only utilitarian motivations, but also moral ones, and that the latter play a primary role in their emergence. This theory asserts that normative incentives are not only found in moral and legal rules, in moral consciousness and in practical reason, or in individual or collective deliberation--- rather, they are underpinnings of the normative content of given feelings. Therefore, one can distinguish different claims at work in social movements with regard to the various types of feelings of injustice they are rooted in: some of these feelings refer to disrespect (a lack of recognition of the universal value of my freedom) while others refer to dishonour (a lack of recognition of the social value of my activity).

It is worth noting that in Honneth, the struggle for recognition has only a loose link with what one usually terms "identity". Indeed, Honneth states that the positive relationship with oneself that defines (positive) identity depends on others' speeches and deeds, so that identity depends on and must be confirmed by recognition. In a way, the normativity of recognition rests upon individual efforts to preserve an unharmed personal identity. However, personal identity is reduced to an abstract positive relationship with oneself that is specified in three forms--- self-confidence, self-respect and self-confidence--- each

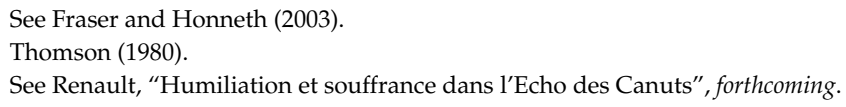


one depending on a universal form of demand for recognition: recognition of my value as a body and psychic life, recognition of the value of my freedom and recognition of the value of my social life. ${ }^{6}$ Thus, personal identity is conceived of as a mere form, and cut off from the content of the various collective identities that compose it. Now, the issue at stake is whether or not such a sharp distinction is possible between the recognition of the three kinds of positive relationships to oneself and the recognition of the collective parts of personal identity. On the level of phenomenological analysis, self-confidence, self-respect and self-esteem seem to be negatively linked with the various collective features of personal identity: racism, unemployment, stigmatization can destroy them. Furthermore, it is quite clear that there is a positive link between these two levels of recognition. For example, when employees do not identify with their professional activity, they have difficulty viewing their wages as recognition of the social value of their existence. In many cases, though not in all, it is through recognition of the collective value of their professions that they can find recognition of the social value of their work. Finally, the normative content of recognition has to be conceived of in a broader way so that it subsumes the recognition of personal identity (as positive relation to oneself) as well as the recognition of the collective identities which comprise it. Understood in this way, the theory of recognition provides a means not only for analyzing cultural politics (as in Taylor) or minority politics (as in Fraser), but also for examining the larger scale of political problems rooted in social identities.?

\section{STRUGGLES OF RECOGNITION AND PROTEST ACTION}

Understood in this Honnethian sense, the theory of recognition helps investigate the practical logic and the normative dynamics of protest actions. In particular, it can describe the continuity between pre-political and political protest actions. ${ }^{8}$

One is often tempted to refuse to give pre-political protest actions (such as riots or other forms of collective violence) any kind of legitimacy. However, it would be wrong to conclude that a feeling is always irrational when it is not rationally articulated, or that legitimacy depends only on universal rights and social justice, separate from individual motivations and psychological factors. The ethics of recognition can be used to elaborate a normative framework at the level of motivation for protest actions in order to describe its normative dynamic and its specific claims to validity. It can be used to show how various forms of the social denial of recognition can lead individuals to react in different ways and with different means against the social injustice they experience. Furthermore, it can be seen that the motivational basis for political action (in the classical sense of the term) is not a positive representation of moral principles. Rather, it comes from experiences of what is no longer bearable, i.e. feelings and practical reactions to peculiar social situations. Under these conditions, the theory of recognition helps to disclose the political content of some apparently pre-political protest actions. An analysis of the demand for "respect" in 
the French revolts of "Banlieues", in November 2005, provides a good illustration of such possible disclosure. ${ }^{9}$ Politicians, journalists and social scientists have usually said that this revolt was not political because they were surprised by the lack of political demands and because they assumed that the demand for respect was not political. However, it is unclear whether the social disrespect that young immigrants constantly face (unemployment, geographical marginalization and racism) is completely unrelated to social injustice. Since violence here is consciously oriented against symbols of social injustice it can be said that it has political content.

Such dynamics of politicization, based on a lack of recognition, can be described at the very level of individual interactions. For instance, the Punk movement, at its beginning, might be described as an attempt to politicize ordinary interactions by seeking to transpose society's condescension, fixed on the young unemployed men and women of the English working class. ${ }^{10}$ Instead of merely reversing the stigma, the punks engaged in a struggle of recognition by identifying themselves (their body, their clothes) with what was socially considered to be the most unbearable in order to denounce both social structures and conventions and their social fate. Here again, politicians as well as journalists and social scientists reduced punk practices to psychological reactions (teenager revolt) or to cultural movements (an esthetics of chaos or a dada avant-guard). Even if the Punk movement has always used a classical political discourse (that of anarchism above all), many are still unable to describe what was (and still is) political in such practices, and therefore conclude that these discourses are only superficial.

Even when protest actions are more classically associated with articulated political discourses, one has to admit that the logic of political action cannot only be conceived of as an effort toward consensus. It can also be conceived of according to an agonistic logic. One problem we face is deciding how political theory must articulate these two dimensions. The theory of recognition offers a model for how to think of such an articulation and how to distinguish its different forms. ${ }^{11}$ When individuals or social groups are victims of a denial of recognition, the only means for them to obtain recognition is through a struggle of recognition. Such a struggle, however, can have two forms: an agonistic or a consensual struggle of recognition. Only the latter deserves the term "struggle for recognition".

In some cases, a struggle aims only to make the denial of recognition disappear. To achieve this goal, it seeks to alter the social context at work in the denial of recognition, for instance, by trying to increase wages for the devaluated professions, or by enforcing laws that forbid humiliating treatments. But this goal can also be worked out by attempts to alter the actions of those individuals that are producing the denial of recognition. This is the case when a struggle of recognition seeks to obtain, by violent means, what it fails to achieve through non-violence. By simply being engaged unwillingly in a struggle with them, individuals and groups who deny recognition to others must take notice of the existence of the victims of their denial. Furthermore, if they lose the struggle, they may 
be forced to change their behavior. Punk politics provides us with a particularly good illustration of such a political strategy.

Other struggles of recognition are clearly oriented toward consensus. This is the case when one group wants to convince another group to recognize its right to practice a given religion or to speak a given language. In such instances (and only in such instances), struggles of recognition are struggles for recognition. Insofar as all struggles of recognition are initiated by a symbolic conflict (that of denial of recognition), the struggle for recognition is here a struggle for reconciliation. These struggles are unlike agonistic struggles of recognition, such as Punk politics where, on the one hand, the struggle wants to deepen the conflict (spreading it even in the most simple and ordinary street interactions) in order to find a solution and, on the other hand, embed the conflict beneath the level of language, intervening only violently (with music and mottos) in the public political sphere. Indeed, these agonistic struggles of recognition are not totally cut off from struggles for recognition, but struggles for recognition only take place inside of the struggling group.

As a matter of fact, the relationship between recognition and reconciliation raises a tricky problem. At first glance, the idea of recognition evokes that of reconciliation, and many critics of Honneth (and others) charge the theory of recognition with presupposing a "consensual" definition of politics or with presupposing that "social reconciliation" is possible. As I have suggested, such criticisms result mainly from confusion between struggles of recognition and struggles for recognition. This confusion could be traced back to the current Hegel reception. Curiously, Hegel is usually viewed as the philosopher of "struggles for recognition", whereas in his mature works, he mainly speaks of the "struggle of recognizing". ${ }^{12}$ Conversely, one might argue that when struggles of recognition lose their consensual strive, they also lose all their normative content. Still, agonistic struggles of recognition remain intimately associated with a consensual dimension insofar as the experience of injustice, triggering the dynamic of refusal, is associated with a positive counterpart, a kind of telos of a more egalitarian distribution of recognition in society. When individuals and groups fight against social contempt, they do not just fight against individuals and groups denying them recognition. Rather, they are more or less explicitly driven by a normative dynamic aiming at a social order which would provide self-confidence, self-respect and self-esteem to all individuals. It is clear that this telos belongs to the normative dynamic of protest and political actions but not necessarily to their explicit goals.

Another important point is that the denial of recognition implies a practical dynamic (of escape, resistance or adaptation): a critique of the social principle that justifies what is unbearable and an attempt to articulate claims. ${ }^{13}$ In its development, a social movement elaborates some kind of self-reflection on its norms and aims, as well as a characterization of its enemies and allies. A political discourse results form this self-reflection and this discourse has to be judged from a normative standpoint. One interest of the theory of 
recognition is to show that the question of the normative dynamic of political action must be distinguished from the question of the value of the means and ends of political action, and considered as such. Some political action may rest upon legitimate claims without working towards a legitimate aim, or without using legitimate means (for example, in the case of urban collective violence). Another interest is to take the standpoint of this normative dynamic itself to propose a truly political judgment on the value of these aims. Note that this is a significant departure from taking an external standpoint, like a moral or legal one, or from taking even the standpoint of institutionalized political language. It is clear, however, that not every struggle against denials of recognition is political. It is only when individuals and groups are fighting against the denial of recognition produced by the institutions of social life that their struggle is political and that it really involves political normativity. Conversely, it is only if the theory of recognition is able to explain when institutions produce recognition or denial of recognition that it is able to make the political aspects and the normative dynamics of social conflicts explicit.

\section{VARIOUS FORMS OF STRUGGLE OF RECOGNITION}

In order to distinguish the different forms of struggles of recognition, one has to begin by differentiating between various kinds of denials of recognition. ${ }^{14}$ As Fraser plainly states, institutions produce effects of recognition because they incarnate normative schemes: they discriminate amongst individuals according to the normative assumptions of their functioning. Institutions, however, refer to various kinds of normative principles: rules, norms and identities.

Insofar as the rules of interaction condition the way others behave towards me, they have a direct influence on the recognition (or lack thereof) of my individual value. Rules of interaction necessitate the attribution of a social role to an agent, a qualification of the action and a context of action in which others intervene. These evaluations of the agent and his partners, through the rules of interaction, produce effects of recognition and possible denials of recognition. This type of a denial of recognition is specifically linked to rules and could be termed depreciating recognition. It can take three different forms: 1. Devaluation or recognition as inferior, recognition of an individual as a subordinate partner in a hierarchical context of action, for example, a worker in his relationship with the foreman. 2. Disqualification or recognition of an individual as not fulfilling the criteria which define a partner of interaction, whatever the context of action, for example, a young immigrants refused entry to a night-club. 3. Stigmatisation, the recognition of an individual as an agent of noxious or condemnable actions, a typical experience for Romani people.

A second type of denial of recognition concerns the mobilization of subjectivities by norms. The institutional coordination of actions through rules is often reinforced by the intervention of norms, to which individuals attempt to conform, and through specific mechanisms that aim to have individuals adjust their behaviour to these norms. For instance, let us 
think of the valorisation of self-presentation and a specific knowing-"how-to-be" within school institutions and in workplaces..$^{15}$ The resulting effects of subjectivation can bring about a new type of denial of recognition. In institutions that offer recognition only to those individuals who strive to stick as closely as possible to their predetermined roles, the denial of recognition takes the form of misrecognition. Here, the denial of recognition is produced by social identification itself, and no longer by social evaluations associated with social identification. The first type of misrecognition is inadequate recognition, when individuals within institutions are forced to embrace roles with which they cannot identify. A typical example is that of employees who have to fit completely with the "culture" of their firm in order to get hired, even if they cannot identify themselves with their job. The second type of misrecognition is invisibility ${ }^{16}$, for example, the racial invisibility of black ${ }^{17}$, the gendered invisibility of domestic work ${ }^{18}$, or the social invisibility of industrial workers. ${ }^{19}$ The third is "over-visibility", for example the over-visibility through which a black man becomes nothing other than a black ${ }^{20}$, or the over-visibility through which Europeans sometimes feel invaded by Arabs. ${ }^{21}$

A third type of denial of recognition has to do with the constitution of identity. Throughout socialization, the different institutional spaces allow each individual a representation of the specificity and value of their existence. In that sense, they become spaces in which the different components of personal identity are constituted. In fact, in this case, the effect of recognition is twofold since socialization and the constitution of identities must not be viewed as the imposition of social norms on an uninformed subjectivity. Rather, these processes must be understood as a means by which subjective transaction, the unification by the individual of the different components of his identity, parallels a process of objective transaction between his own expectations and those of the institution. In such a process of subjectivation, recognition relates to identity both as something that conditions it and something that is conditioned by it. This specific function of recognition leads to a third type of denial of recognition which I term unsatisfactory recognition. Effects of subjectivation are unsatisfactory when they do not allow individuals to fully identify with the different roles they would like society to recognize. The problem here is not that the individual does not achieve recognition of the manner in which he/she embraces these roles, which would be misrecognition, but that these different roles pile themselves up in him/her without him/her being able to achieve a personal unification that would give him/her the feeling of being recognized through them. The problem is not that social identification contradicts the expectation of recognition, but that there is a contradiction in the expectation of recognition itself. Such a denial of recognition can take two forms: the first is that of

For a critical study of the demand and evaluation of the "how-to-be: in the new management, see Neyrat (2001).

16 See Honneth (2003a). On invisibility, see also Voirol (2005).

17 See Ellison (1947).

18 See Recherches féministes, 1999: "Invisibles et visibles".

19 See Beaud and Pialoux (1999).

20 Fanon (1952), ch. 4.

21 One may question whether what Butler terms the invisibility of transgender individual is not rather a mix of invisibility and over-visibility (see Butler, 2006). 
unstable recognition. This is the situation where the individual drifts between social roles without being able to unify them in a coherent narrative so that he/she cannot give his / her existence a satisfying meaning. Such a situation is described by Richard Sennett in his book The Corrosion of Character, with reference to the new workers of flexible capitalism. ${ }^{22}$ The second type of denial of recognition is unsatisfactory recognition which takes the form of a recognition that splits or tears apart subjectivity in those cases where an institutional context makes strong identifications possible but also incompatible. This is the case when, as early as primary socialization, individuals are caught up in institutional mechanisms that are not necessarily compatible. A classical illustration is the situation of second or third generation immigrants who find it difficult to unify cultural codes from the family sphere with codes from school and other spaces of social life.

\begin{tabular}{llll}
\hline $\begin{array}{l}\text { Institutional } \\
\text { mechanisms }\end{array}$ & $\begin{array}{l}\text { Identification of partner } \\
\text { in action }\end{array}$ & $\begin{array}{l}\text { Mobilisation of } \\
\text { subjectivities }\end{array}$ & $\begin{array}{l}\text { Identity construction in } \\
\text { socialisation processes }\end{array}$ \\
\hline $\begin{array}{l}\text { Genres of denial of } \\
\text { recognition }\end{array}$ & Depreciative recognition & Misrecognition & Unsatisfactory recognition \\
\hline $\begin{array}{l}\text { Subgenres of denial of -devaluing } \\
\text { recognition }\end{array}$ & -disqualifying & -Inadequate recognition & -unstable \\
& -stigmatising & -Ovisibility & -splitting or tearing apart \\
\hline
\end{tabular}

A reason why the normative dynamics of struggles of recognition are not easy to describe is that these various forms of denial of recognition often interfere. In such cases, it is always a problem for the individual or the group concerned to identify the best way to struggle against the denial of recognition. This problem leads us to the classical issue of the intersection between different kinds of domination: when one suffers from class contempt, racist discrimination, stigmatisation, invisibility or over-visibility, sexist discrimination or invisibility, the distinction between allies and enemies is unclear or the strategies of struggle often end up in an aporia. These aporia may result from possible conflicts between objectives -for instance, it is often the case that poor people and immigrants are accused of sexism-; or, result from a conflit between strategies - for instance, a struggle for visibility is always a struggle for recognition, but the repertories of collective action for struggles for recognition and struggles for visibility are quite different.

Moreover, when various types of denials of recognition are intertwined, it is difficult to know which motivation plays the greater role in the emergence and development of the collective mobilization. This analytical problem is deepened by the fact that explicit demands of recognition are not always the same as those that are at stake in real practices. Individuals are usually not aware of their expectations of recognition, and it is only after a denial of recognition that they are made explicit through claims. Yet, this reflexive stance is far from being free from psychological and social constraints. Different processes can impede individuals to admit or to articulate their expectations of recognition. For instance, 
it has been noted that employees admit to expecting recognition from their colleagues while it is often recognition from those higher up that they value more. ${ }^{23}$

Another analytical problem is that claims of recognition can have different statuses. Positive recognition can constitute the core of a claim, but it can also have only a strategic function. Indeed, social groups can seek to be recognized through normative principles which constitute no more than a means of improving their position in society. For instance, Ferdinand Sütterluty has analyzed how, in Germany, an association of Muslim immigrants from Turkey offered to donate blood to the Red Cross. ${ }^{24}$ The Red Cross was the recipient of this proposal because of its symbolic weight (Christian, it is the symbol of German recognition) and also because of the universality proclaimed in its charter (all can be helped and all can participate regardless of their origin or religion). This association of immigrants is perfectly aware of the prejudices held by the Red Cross against "Turkish blood". Basically, it is this awareness that led the group to carry out their symbolic struggle on this front. Its political objective was not to benefit from the universal recognition it is supposed to allow, but only to use the official universalism of the Red Cross to force it to recognize the dignity of "Turkish blood", and thus to use its symbolic prestige to improve its place in the society.

If one relies exclusively on Bourdieu's theory, the issue of recognition would be reduced to conflicts that oppose groups in order to impose their vision of the world, and the struggle of recognition would only have a strategic function, such as the one just mentioned. ${ }^{25}$ However, we have seen that there are many reasons to assert that some struggles of recognition are rooted in the normative content of personal identity and thus cannot be interpreted solely in a strategic way. If one relies exclusively on the model set up by Fraser, one should only take into account those non-strategic struggles of recognition that are restricted to problems about the social status of groups, according to a strict opposition between recognition and redistribution. But there are many reasons to think that problems of distribution are also lived and experienced as problems of recognition by the individuals involved, and that the experience of injustice, in general, is an experience of a denial of recognition. If one relies exclusively on the theory worked out by Honneth, one would have to identify all struggles against the denial of recognition as struggles for recognition. But, as I have suggested, it is useful to distinguish agonistic from consensual struggles of recognition. Ultimately, it is preferable in an analysis of claims of recognition to use the whole range of distinctions that has just been presented (typology of denial of recognition, distinction between implicit and explicit recognition expectations, distinction between instrumental and normative struggles of recognition, of agonistic and consensual ones) in order to avoid unilateral analyses that run the risk of theoretical simplification and a fundamental misunderstanding of their specific political contents and legitimacy.

23 Kocyba (2007).

24 Sutterlüty (2006).

25 For a critical discussion of Bourdieu's theory of recognition, see Voirol (2004). 


\section{REFERENCES}

Beaud, Stéphane. Pialoux, Michel. 1999. Retour sur la condition ouvrière. Paris: Fayard.

Butler, Judith. 2006. "La question de la transformation sociale". In Défaire le genre. Paris: Editions Amsterdam.

Deranty, Jean-Philippe. Renault, Emmanuel. 2007. "Politicising Honneth's Ethics of Recognition". Thesis Eleven 88.

Ellison, Ralph. 1947. Invisible Man. New York: The New American Library.

Fanon, Frantz. 1952. Peau noire, masques blancs. Paris: Seuil.

Fraser, Nancy. 1995. "From Redistribution to Recognition? Dilemna of Justice in a Postsocialist Age". New Left Review 212.

Fraser, Nancy. Honneth, Axel. 2003. Redistribution or Recognition? A Political-Philosophical Exchange. London: Verso.

Honneth, Axel. 1995. The Struggle for Recognition: The Moral Grammar of Social Conflicts. Cambridge: Polity Press.

Honneth, Axel. 2003a. "Unsichbarkeit". In Unsichtbarkeit. Frankfurt: Suhrkamp, Frankfurt.

Kocyba, Hermann. 2007. "Reconnaissance, subjectivité, singularité". Travailler 18.

Neyrat, Frédéric. 2001. “Les chômeurs à l'épreuve de la compétence. Justifications et usages du nouveau ROME (Répertoire opérationnel des métiers et des emplois)". Les Cahiers du Laboratoire Georges Friedmann 9.

Renault, Emmanuel. "Humiliation et souffrance dans l'Echo des Canuts", forthcoming. 2004a. "European Conceptions of Identity". In M. Mamdani (ed.), Keywords: Identity. New York: Other Press.

2004b. L'expérience de l'injustice. Paris: La découverte.

2007a. "Le discours du respect". In A. Caillé (ed.), La Quête de reconnaissance. Regards sociologiques. Paris: La Découverte.

2008a. "Theory of Recognition and Critique of Institution". In Danielle Petherbridge (ed.), The Critical Theory of Axel Honneth. Leiden: Brill Academic Publishers.

. Forthcoming. "Reconnaissance: qu'est-ce que le modèle hégélien?".

Renault, Emmanuel, Zeneidi, Djemila. 2008b. "Formes de reconnaissance conflictuelle: relations sociales, appropriation de territoire, culture et politique dans un groupe de punks squatters". In J.-P. Payet, A. Battegay (ed.), La reconnaissance à l'épreuve. Explorations socio-anthropologiques. Bern: Peter Lang.

Sennett, Richard. 1998. The Corrosion of Character. The Personal Consequences of Work in the New Capitalism. New York: W. W. Norton and Company.

Sutterlüty, Ferdinand. 2006. "Blutsbande. Ethnische "Verwandtschaft" als Tiefendimension sozialer Ungleichheit". WestEnd. Neue Zeitschrift für Sozialforschung 3.1.

Taylor, Charles. 1992. Multiculturalism and the "Politics of Recognition". Princeton: Princeton University Press.

Thomson, E. P. 1980. The Making of the English Working Class. London: Gollancz.

Voirol, Olivier. 2004. "Reconnaissance et méconnaissance. Sur la théorie bourdieusienne de la violence symbolique". Information sur les sciences sociales 43 (3).

2005. "Visibilité et invisibilité: une introduction". Réseaux, n 129-130.

Zeneidi, Djemila. 2008b. Punk: une géographie de la reconnaissance. Paris: Bréal. 
Emmanuel Renault es profesor adjunto de filosofía en le Ecole Normale Superieure de Lyon. Entre sus más recientes publicaciones se encuentran dos libros sobre el reconocimiento: La experiencia de la injusticia. Reconocimiento y clínica de la injusticia (publicado por La Decouverte en 2004) y Desprecio social. Ética y política del reconocimiento (cuya segunda edición fue publicada por Éditions du Passant también en 2004). Es también el autor de dos libros sobre Marx: Marx y la idea de la crítica (PUF, 1995) y El vocabulario de Marx (Ellipses, 2001), y de dos libros sobre Hegel: La naturalización de la dialéctica del 2001 (Vrin) y Filosofía química. Hegel y la ciencia dinámica de su tiempo publicado en el 2002 (PUF). Él es el editor de dos revistas internacionales, Actuel Marx y Critical Horizons. En este momento está terminando un libro sobre el sufrimiento social. 